\title{
Dile Getirme Davranışı (Voice Behavior) Ölçeğinin Türkçe Adaptasyonu: Geçerlik ve Güvenirlik Çalışması
}

\author{
Turkish Adaptation of Voice Behavior Scale: A Validity and Reliability Study
}

\section{Öğr. Gör. Doğancan Çavmak ${ }^{1}$ - Doç. Dr. Özgür Demirtaş}

Başvuru Tarihi: 22.11.2019

Kabul Tarihi: 30.04.2020

Makale Türü: Araştırma Makalesi

Öz

Dile getirme davranışı son yıllarda birçok araştırma modelinin odaklandiğı bir konu haline gelmiştir. Özellikle örgütsel davranış alanında liderlik, motivasyon, bağlılık, aidiyet gibi çeşitli konular ile daha çok gündeme gelen bu kavrama yönelik henüz Türkçe literatürde kullanımı mevcut bir Türkçe 'ye uyarlanmış ölçeğe rastlanılmamıştır. Bu kapsamda mevcut çalışmada, dile getirme davranışı ölçeğinin, Türkçe'ye uyarlanması ve geçerlik-güvenirliğinin test edilmesi amaçlanmıştır. Türkçe literatürde önemli bir boşluğu dolduracağı değerlendirilen çalışmanın örneklemi İstanbul ilinde, çalışmaya katılmayı kabul eden 4 özel hastaneden, yöneticiler, birim sorumluları ve ekip liderleri ile gerçekleştirilmiştir. Türkçe'ye çevrilen ölçeğin, kapsam ve yapı geçerliliği ile güvenirliği test edilmiştir. Analizler sonucunda ölçeğin uygun, geçerli ve güvenilir sonuçlar verdiği gözlenmiştir.

Anahtar Kelimeler: Dile Getirme Davranışı, Örgütsel Davranış, Ölçek Geliştirme

\begin{abstract}
In recent years, voice behavior has become an important topic that many research models focus on. From the literature review, we saw that there is no scale adapted to Turkish for this concept, which has come to the front especially in the field of organizational behavior with various concepts such as leadership, motivation, commitment and identification. In this context, in the current study, it was aimed to adapt the voice behavior scale to Turkish and test its validity and reliability. The sample of the study, which is considered to fill an important gap in the Turkish literature, was carried out in Istanbul province with managers, unit managers and teamleaders from 4 private hospitals that agreed to participate in the study. As a result of the analyzes, it was observed that the scale is appropriate, valid and reliable.
\end{abstract}

Keywords: Voice Behavior, Organizational Behavior, Scale Development

\footnotetext{
1 Tarsus Üniversitesi, Sağllk Hizmetleri Meslek Yüksekokulu, dogancavmak@tarsus.edu.tr, ORCID: 0000-0002-3329-4573

${ }^{2}$ Kayseri Üniversitesi, Sosyal ve Beşeri Bilimler Fakültesi, ozgurdemirtas@kayseri.edu.tr, ORCID: 0000-0002-2495-2124
} 


\section{Giriş}

Çalışanların motivasyonu, yöneticiler için temel uğraşı alanlarından biri olarak önemini devam ettirmektedir. Örgütsel fonksiyonların etkin bir şekilde işlemesi için en önemli girdi insan kaynağıdır. Örgütlerin amaçlarına ulaşmalarında; motive olmuş, örgütsel gelişim için sorumluluk hisseden, yapıcı fikirler geliştiren ve bu fikirleri dile getirmekten çekinmeyen insan kaynağı oldukça gerekli bir konudur. Bir örgütte, sorunları veya gelişim önerilerini dile getirmekten çekinen insan kaynağının varlığı, değer taşıyan fikirlerden yararlanılamadığının bir işaretidir. Değişimin oldukça hızlı gerçekleştiği, rekabetin yoğun olduğu günümüz ekonomik yaşantısında; güçlü ve kaliteli iletişim, proaktif yaklaşım ve yeni fikirlerin geliştirilmesi, insan kaynağından aranan temel yeterlilikler arasında yer edinmiştir.

Dile getirme davranışı; bir çalışanın çalışma alanı ve grubu ile ilgili olası sorunlara ilişkin fikirlerini, çözüm önerilerini veya endişelerini, kendi isteği ile yukarı yönlü bir iletişim dâhilinde ifade etmesi olarak tanımlanabilir (Morrison, 2014, s. 174). Yapılan birçok değerlendirmede dile getirme davranışının örgütler için önemli kazanımlar sağladığı ifade edilmektedir (Morrison, 2011, s. 374 ; LePine ve Van Dyne, 1998, s. 853).

Çalışanların fikirlerini dile getirebilecekleri ve değer gördüklerini hissedebilecekleri bir örgüt kültürünü oluşturma noktasında, önemli bir sorumluluk payı liderler ve yöneticilere düşmektedir. Liderlerin çalışanları ile olan etkileşiminin, onlardan beklentilerinin ve sağlamış oldukları geri beslemelerin, çalışanların sorumluluk alma ve geliştirici fikirler üretmeleri üzerinde anlamlı etkileri olduğu tespit edilmiştir (Duan vd., 2017, s. 658; Wu vd., 2010, s. 25). İşgörenlerin örgüte katkı sağlamak adına sergilediği bu davranış olan dile getirme davranışı, liderler için hem önemli bir araç hem de değerli bir göstergedir.

Çalışanların fikirlerini ve önerilerini, yönetici ve liderleri ile gönüllü bir şekilde paylaşabilmelerinin ve sorumluluk almalarının bireysel iş performansını arttırdı̆̆ı ve örgütsel verimliliği arttırdığı ifade edilmektedir (Kim vd., 2010, s. 387). Ayrıca, dile getirme davranışı yüksek olan çalışanların, örgüt içerisinde imajlarının daha yüksek olduğu ve işlerine olan bağlılıkların olumlu yönde geliştiği tespit edilmiştir (McClean vd., 2018, s. 1879-80).

$\mathrm{Bu}$ çalışmada; liderlerin, çalışanların dile getirme davranışlarını analiz edebilmeleri ve böylece daha etkin bir örgütsel yapıyı tahsis edebilmek için doğru verilere ulaşabilmeleri amacıyla, LePine ve Van Dyne (1998, s. 860) tarafından geliştirilen “Dile Getirme Davranışı Ölçeği” nin (Voice Behavior Scale), Türkçe uyarlamasını yapmak amaçlanmıştır. Uyarlama çalışması, en önemli ve büyük sağlık işletmeleri olan hastanelerin yöneticileri ile yapılan anket uygulaması ile gerçekleştirilmiştir.

Anket uygulaması özellikle dile getirme davranışlarının önemli etkide bulunacağı düşünülen Sağlık İşletmeleri kapsamında gerçekleştirilmiştir. Çünkü sağlık işletmeleri, yapısı gereği oldukça karmaşık yapılardır. İkili otorite hattının (matriks) mevcudiyeti, çalışanlar arası iletişimin oldukça güçlü ve yapıcı olmasını gerekli kılmaktadır. Sağlık çalışanları arasındaki iletişim kopukluğu, bakım kalitesine ve sağlık çıtılarına doğrudan olumsuz olarak yansımaktadır (Howard vd., 2013). Sağlık işletmelerinde, çalışanların uzmanlaşma derecesi çok yüksektir. Dolayısıyla, sağlık işletmelerinde, insan kaynağının işlerini yüksek değer üreten alanlar olarak görme ve bağımsızlaşma eğilimi görülebilmektedir. Sağlık işletmeleri 
yöneticilerinin veya liderlerinin, bir taraftan yüksek beklentileri olan hizmet kullanıcılarını tatmin etmek uğraşısı varken bir taraftan da yapıcı bir örgüt kültürü yaratma zorunlulukları bulunmaktadır.

Liderler; finans ve kalite baskısını yaşarken, insan kaynağı için de uzlaşmacı ve etik bir iklim oluşturmak zorundadır (Chamber, 2011, s. 378). Bahsi geçen tüm bu ayırt edici özellikler, esasen, sağlık işletmeleri için dile getirme davranışının önemini ortaya koymaktadır. Yapılan bazı çalışmalar (Schwappach ve Richard, 2018, s. 1), dile getirme davranışının, sağlık işletmeleri için önemli bir kazanım olduğunu ve bu davranışın örgüt kültürü ile yüksek düzeyde ilişkili olduğu göstermesine rağmen, bu alanda yapılan çalışmaların henüz yeterli düzeyde olmadığı da gözlenmiştir. Bu kapsamda mevcut çalışmanın alan yazına ve aynı zamanda uygulayıcılara en önemli katkısının, lider ve yöneticiler gözünden değerlendirme yapmayı mümkün kılacak bir ölçüm aracı tasarlıyor olmasıdır. Çalışmanın alan yazınına bir diğer katkısı ise, dile getirme davranışı teorisinin ve ilişkili kavramlarının tartışmasını sunuyor olmasıdır.

\section{Kavramsal Çerçeve}

Dile getirme davranışı (voice behavior) kavramının farklı tanımlamaları mevcuttur. LePine ve Van Dyne (1998) tarafından, dile getirme davranışı; "informal olarak gerçekleşen, örgütsel iyileştirmeler sağlayan yapıcı fikirlerin dile getirilmesi, duyurulması” olarak tanımlanmıştır. Başka bir tanımda ise yine benzer noktalar vurgulanarak, "örgüt yararına olacak şekilde sergilenen gönüllü ve planlı davranışlar, söylemler” ifadesi kullanılmıştır (Detert ve Burris, 2007, s. 370).

Dile getirme davranışı kavramının; çalışanların, örgütsel süreç içerisinde iyileştirilmesi gereken hususlara yönelik hissettikleri huzursuzluk ve memnuniyetsizlikten kaynaklandığı ifade edilmektedir (Detert ve Burris, 2007, s. 370). Bunun yanı sıra, dile getirme davranışı için, bu memnuniyetsizliği hisseden çalışanların, örgüt içerisinde fikirlerini belirtmek ve iyileştirme çalışmaları yapmak için fırsatlarının olduğuna inanmaları ve örgüt kültürünün de buna uygun olması şartları aranmaktadır. Aksi takdirde, çalışanlar için fikir belirtmek veya gönüllü olarak sorumluluk almak bir risk olarak algılanmaktadır (Detert ve Burris, 2007, s. 372).

$\mathrm{Bu}$ alandaki en önemli araştırma sorularından biri, "çalışanlar neden dile getirme davranışı gösterirler veya göstermezler” olagelmiştir. Bu davranışı açılamak üzere geliştirilen modellerde, bireylerin, ilgili davranışın hem olumlu hem olumsuz çıktılarını değerlendirerek bilinçli bir karar vardıkları vurgulanmaktadır (Detert ve Burris, 2007). Bu yaklaşım çerçevesinde, dile getirme davranışının tetikleyicilerinin ve bu davranışı etkileyen faktörlerin neler olduğu ile yaklaşımda iki temel bileşen ön plana çıkmaktadır. Bunlardan ilki; "dile getirme davranışının etkililiği üzerine çalışanların algı düzeyleridir”. Bu boyut, insan kaynă̆ının, fikirlerini belirtme ve proaktif davranma hususundaki kişisel yargılamalarını ifade etmektedir. İkinci önemli bir boyut ise, dile getirme davranışına yönelik güven algısı ile ilgilidir (Morrison, 2011, s. 382). Aşağıdaki Şekil 1'de, dile getirme davranışı modeli görselleştirilmiştir. 


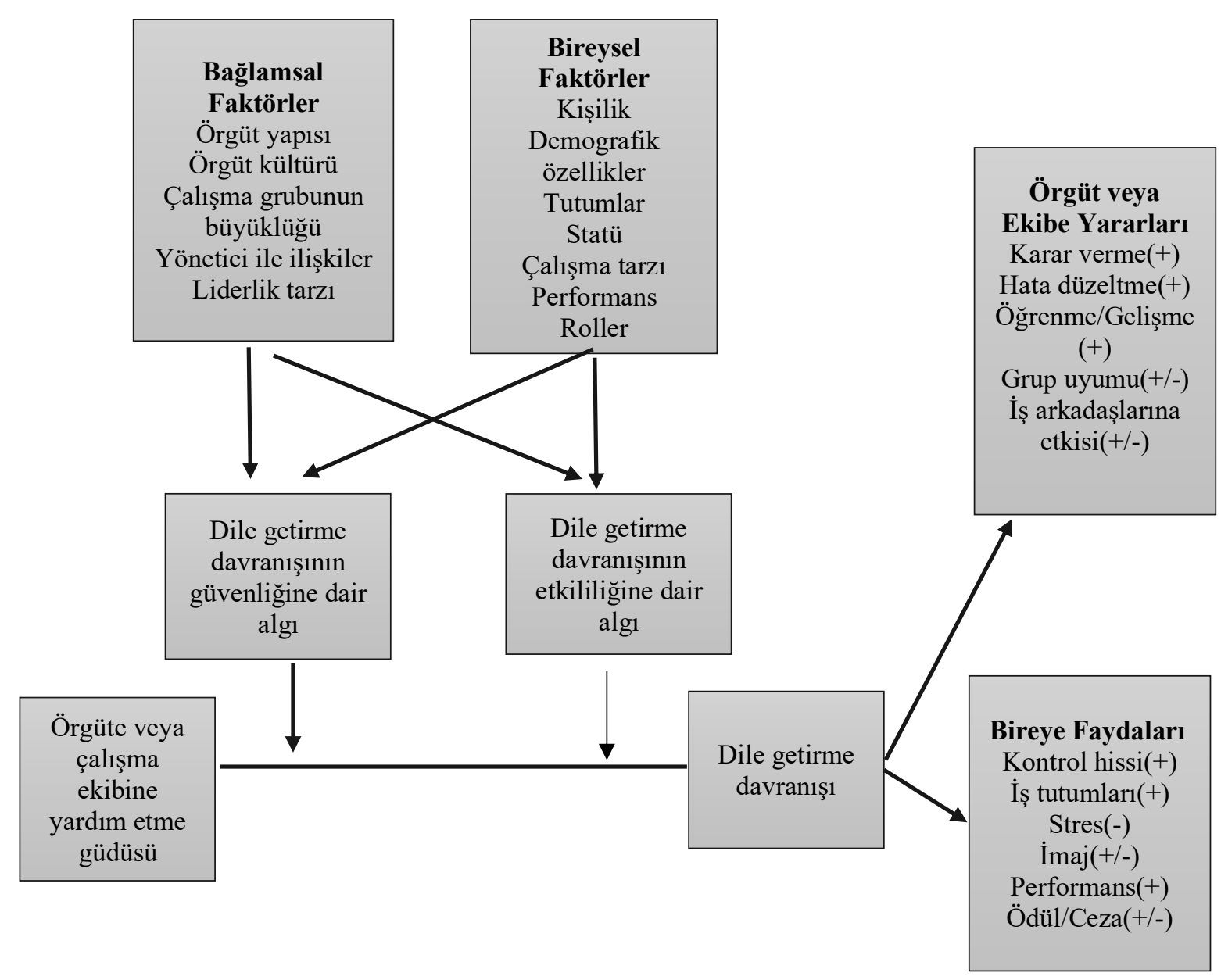

Kaynak: Morrison, 2011, s. 382

\section{Şekil 1. Dile Getirme Davranışı Modeli}

Morrison (2011) tarafindan sunulan bu modelin, motivasyon teorilerinden olan "beklenti teorisi” ile tutarlılık gösterdiği ifade edilmektedir. Bireyin davranışı göstermesi sonucu elde etmeyi beklediği çıktıların, davranış için önemli bir belirleyici olduğu ifade edilmektedir. (Morrison, 2011, s. 382-383). Model ayrıca, dile getirme davranışının, bağlamsal ve kişisel faktörlerin bir fonksiyonu olduğunu da iddia etmektedir. Bireylerin, dile getirme davranışı göstermelerinin arka planında, örgütsel yapının, örgüt kültürünün ve liderlik tarzlarının belirleyici olduğu ifade edilmektedir. Yapılan bazı çalışmalarda örgüt ikliminin, ekibin sahip olduğu ortak değerleri ve fikirleri etkilediği, dile getirme davranışının bir belirleyicisi olduğu (Morrison vd., 2011, s. 188-189), liderlerin değişime yönelik olumlu fikirlerinin ve çalışanların fikirlerini dikkate almasının, dile getirme davranışını olumlu yönde etkilediği (Milliken vd., 2003) tespit edilmiştir. Bireysel karakteristiklerin de, dile getirme davranışı üzerinde anlamlı etkilere sahip olduğuna yönelik çalışmalar mevcuttur. Yapılan çalışmalarda, dışa dönük bireylerin, baskı veya karşıt fikirlere rağmen, görüşlerini dile getirmekten çekinmedikleri (Detert ve Edmondson, 2011, s. 472), kendini koruma güdüsünün yüksek olduğu bireylerin ise, özellikle yanlış olabileceğinden şüphelendikleri fikirleri dile getirmekten çekindikleri veya sorumluluk almak istemedikleri (Pinder ve Harlos, 2001, s. 362-363) tespit edilmiştir. 
Dile getirme davranışı ile ilgili yapılan çalışmalarda yaygın olarak kabul edilen varsayımlardan biri, davranışın sıklığının arttıkça sağlayacağı faydanın da yüksek olacağı inancıdır. Ancak geride bıraktığımız son on yıl içinde, sıklığın ötesinde, davranışın bir sorunun çözümüne veya bir iyileştirme sürecine yönelik olup olmadığı sorusu ön plana çıkmıştır. Günümüzde, dile getirme davranışı, nicelik boyutunun yanı sıra, kalitesi, içeriği ve türleri ile değerlendirilmektedir. Literatürde, öneri odaklı (suggestion focused), problem odaklı (problem focused), fikir odakl1(opinion focused) (Morrsion, 2011, s. 398), teşvik edici(promotive), engelleyici(prohibitive) (Liang vd., 2012, s. 80-81), destekleyici (supportive), savunmac1 (defensive), yıkıcı (destructive) (Maynes ve Podsakoff, 2014, s. 91) olmak üzere birçok türde dile getirme davranışı tanımlanmaktadır.

Dile getirme davranışının kalitesi; irdelenen en önemli boyutlardan biri olma özelliğini halen muhafaza etmektedir. Davranışın kalitesi, iletilen mesajların içeriğini ve nasıl iletildiğini irdelemektedir. Dile getirme davranışının kalitesi ile ilgili kavramlar; açılık(clarity), yapıcı ses tonu(constructive tone), uygun zamanlı (timeliness), ilgililik(relevance), yararlılık(usefulness) ve içgörülülük/ufuk açıcı(insightfulness) olarak ifade edilebilir (Brown ve Levinson, 1987, s. 103-105).

Dile getirme davranışındaki kaliteden beklenti, bir dile getirme davranışının, pratikte işleyebilecek ve fayda sunacak tarzda gerçekleştirilmiş olmasıdır (Long, 2014, s. 184). Ayrıca ifadelerin, diğer çalışanların motivasyonlarını da yükseltebilecek şekilde, konuyla ilgili ve yapıcı olması önemli belirleyicilerdir (Matthews, 2007).

\section{Yöntem}

Bu çalışma, yöneticilerin, çalışanların, dile getirme davranışı özelliklerine yönelik veriler elde edebilecekleri bir ölçüm aracını, kullanılabilir hale getirmeyi amaçlamaktadır. Bu amaca yönelik de emek yoğun bir hizmet alanı olan sağlık sektöründe çalışma gerçekleştirilmiştir. Çünkü sağlık sektöründe bakım kalitesinin ve beklenen çıktıların en önemli belirleyicilerinden biri, insan kaynağının iletişim, uyum ve yapıcı olma yetenekleridir. Tıbbi personelin ve aynı zamanda yönetici ve liderlerin; bir ekip içerisinde uyumlu olarak çalışması, takımla aidiyet oluşturması ve daha iyiye doğru ilerleme için aktif olması beklenir. Bu noktada, liderlerin, insan kaynağının özelliklerini iyi bilmesi ve buna göre yaklaşımlar geliştirmesi önemli bir husustur.

\section{Örneklem ve Verilerin Toplanması}

Ölçek uyarlama ve geliştirme çalışmalarında, örneklem sayısının ne kadar olması gerektiği ile ilgili farklı yaklaşımlar bulunmaktadır. Kimi çalışmalarda, önerme sayısının 5 katı kadar uygun katılımcıya ulaşmanın, geçerlik ve güvenirlik çalışmaları için yeterli olduğu ifade edilmektedir (Nunnally, 1978, s. 180; Comrey ve Lee, 1992, s. 216-217). Kimi çalışmalarda ise, önerme sayısının 10-15 katı kadar katılımcının, çalışmada yer alması gerektiği ifade edilmektedir (Nunnally ve Bernstein, 1994, s. 542 ; Pett vd., 2003, s. 62). Bu çalışmada, önerme sayısının en az 10 katı kadar, uygun katılımcıya ulaşılması amaçlanmıştır. Bu amaç doğrultusunda, çalışma evreni olarak İstanbul ilinde yer alan özel hastaneler hedef olarak belirlenmiştir. Lepine ve Van Dyne (1998) tarafından geliştirilmiş olan 6 önermeli ölçek, İngilizce dil yeterliliği olan iki yabancı dil uzmanı ve iki araştırmacı tarafından Türkçe 'ye çevrilmiş (Ekte sunulmuştur) ve 
anket formu, hastanelerde yöneticilik görevi olan çalışanlara iletilmiştir. 1 hafta arayla yapılan iki hatırlatma aşamasından sonra, 4 farklı özel hastaneden 74 katılımcıdan eksiksiz olarak anketler elde edilmiştir. Ayrıca 10 kişilik bir grupla da test-tekrar testi gerçekleştirilmiştir.

\section{Verilerin Analizi}

Önermeler katılımcılar tarafından 7'li Likert tipi ölçek ile değerlendirilmiştir. İlk aşamada, alanında uzman 6 kişi tarafından her bir önerme, çalışmanın amacına hizmet etme derecesi bakımından değerlendirilmiş ve kapsam geçerliliği indeksi elde edilmiştir. Kapsam geçerliliği sonrası ölçek gönderilmiş ve katılımcılar, değerlendirmelerini kendilerine bağlı bir astları için gerçekleştirmişlerdir. Ölçeğin yapı geçerliliği ve güvenirlik analizleri gerçekleștirilmiştir.

Yapı geçerliliğinde doğrulayıcı faktör analizinden(DFA) (faktör yükleri, açıklanan varyans ve uyum indeksleri); güvenirlik ölçümünde ise Cronbach Alpha ve test-tekrar test korelasyon değerlerinden faydalanılmıştır. Verilerin analizinde SPSS 22.0 ve LISREL 8.80 paket programları kullanılmıştır.

\section{Araştırmanın Etik Yönü}

Araştırma, Tarsus Üniversitesi Bilimsel Araştırma ve Yayın Etiği Kurulunun 05.03.2020 tarihli ve 2020/14 sayılı kararı ile etik yönden uygun bulunmuştur.

\section{Bulgular}

Çalışmaya 4 özel hastaneden; hasta hizmetleri, satın alma, muhasebe, müdürlük, insan kaynakları, pazarlama, acil servis, klinik, sterilizasyon, ameliyathane gibi birimlerden, 74 birim yöneticisi, sorumlusu ve ekip lideri katılmıştır. Katılımcıların \%72'si kadın, \%28’i erkektir. Eğitim durumlarına göre sınıflandırma yapıldığı zaman, \%51 lisans, \%23 lisansüstü ,\%18 ön lisans ve $\% 8$ lise şeklindedir.

\section{Kapsam Geçerliliği}

İngilizce olan önermeler, araştırmacılar tarafından Türkçe' ye çevrilmiştir. Çeviri sırasında İngilizce dil yeterliliği olan 2 yabancı dil uzmanının değerlendirmelerine de başvurulmuştur. İlgili önermeler, sağlık yönetimi ve işletme yönetimi alanlarında uzman, 6 kişi tarafından değerlendirilmiştir. Değerlendirme her bir önerme için, 1 (madde hedeflenen yapıyı ölçmüyor), 2(maddenin ölçek ile alakası düşük), 3(madde hedeflenen yapıyı ölçüyor), şeklinde puanlanmıştır. $1-4$ ve 5 numaralı önermeler, tüm değerlendiriciler tarafından “ 3 ” olarak değerlendirilmiştir. 6 numaralı önerme, 1 uzman tarafından “2” geri kalan tüm uzmanlar tarafından ise " 3 ” olarak puanlanmıştır.1,2,3, 4 ve 6 numaralı önermelerin kapsam geçerlilik oranı “1”, 5 numaralı önermenin kapsam geçerlilik oranı ise 0,833 olarak hesaplanmıştır. Kapsam Geçerlilik İndeksi, her bir önerme için 3 (madde yapıyı ölçüyor) cevabını verenlerin, toplam uzman sayısına bölünmesi ile elde edilen, kapsam geçerlilik oranı değerlerinin, ortalamalarının alınması ile elde edilmiştir. Değerlendirme sonra, ölçeğin Kapsam Geçerlilik İndeksi, 0,972 (5,833/6) olarak hesaplanmıştır.

\section{Yapı Geçerliliği}

Veri setinin Kaiser-Meyer-Olkinve Barlett Küresellik testi değeri 0,921 ve anlamlı bulunmuştur $(\mathrm{p}<0.05)$. Orijinal ölçek, tek faktör ve 6 önermeden oluşmaktadır. Yapı geçerliliğini test etmek 
üzere, Lepine ve Van Dyne (1998) tarafından kullanılmış olan yapı aynen korunmuştur. 6 önerme tek faktörlü yapının, toplam varyansın \%77,50’sini açıkladığı görülmüştür. Doğrulayıcı faktör analizi sonucunda, her bir önermenin faktör yükünün 0,40 'dan yüksek olduğu tespit edilmiştir. Dolayısıyla, herhangi bir önermenin ölçekten dışlanmasına ihtiyaç duyulmamıştır. Önermelerin hata varyanslarının düşük olduğu tespit edilmiştir (0.15-0.32) aralığında). Modelde yer alan tüm parametlerin " $\mathrm{t}$ ” değerlerinin 1.96'ından büyük olduğu görülmüștür.

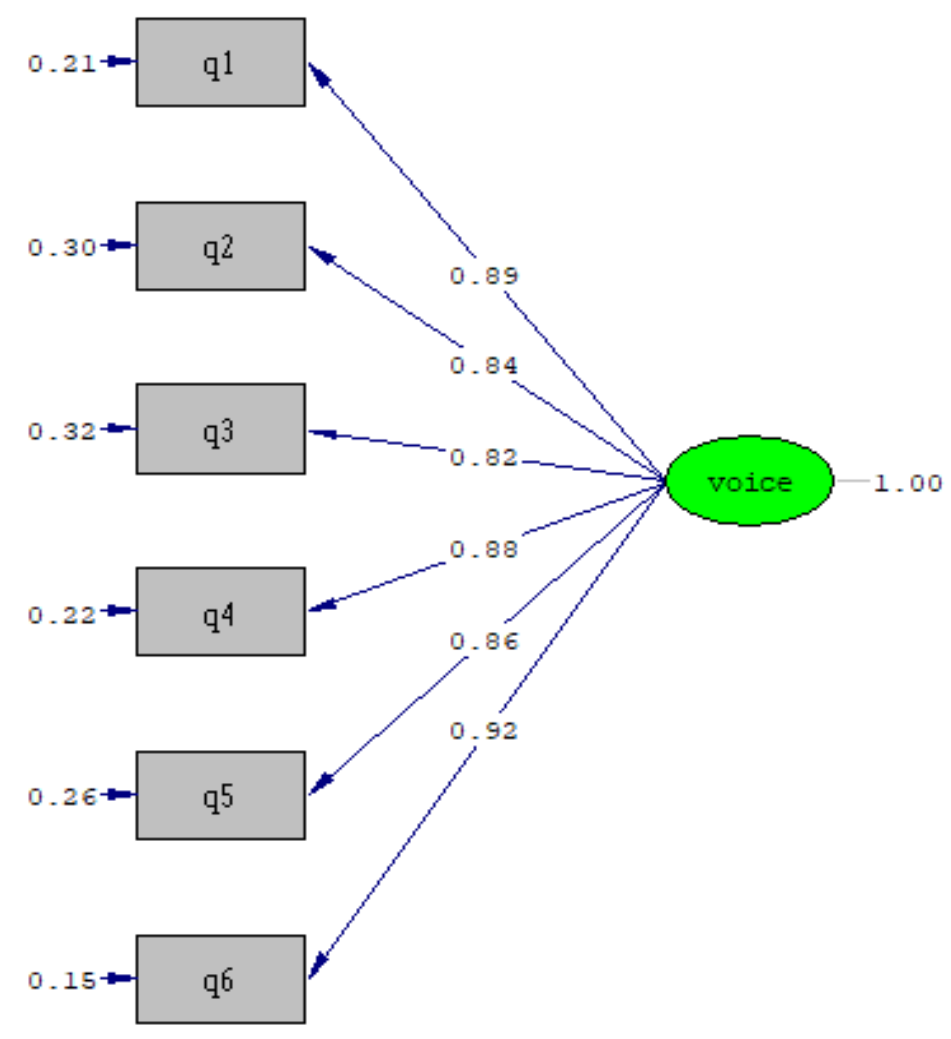

Şekil 2. Model ve Önermelerin Faktör Yükleri

Önermelerin faktör yükleri incelendiği zaman; en düşük faktör yükünün 0.82 , en yüksek faktör yükünün ise 0.92 olduğu görülmektedir (Şekil 2). Faktör yüklerinin yüksek ve anlamlı olması, önermelerin, örtük değişkenle aralarındaki ilişkinin oldukça güçlü olduğunu göstermektedir. Aynı zamanda, önermelerin, katılımcılar nezdinde anlaşılırlığının yüksek olduğunu ve ölçüm amacını yüksek oranda yerine getiriyor olduğu ifade edilebilir. Bu durum, kapsam geçerliliği kapsamında, uzmanlarca verilen değerlendirmelerle tutarlılık göstermektedir.

6 önermeli ve tek faktörlü yapının, örneklemden elde edilmiş olan veri ile uyumunun test edilmesi için uyum indekslerine(fit indices) başvurulmuştur. DFA'da, bir modelin teori ile uyumunu sınamak üzere, birçok farklı göstergeye başvurulmaktadır. Bu uyum indeksleri arasında; $\mathrm{X}^{2}$ (ki-kare), serbestlik derecesi (df), $\mathrm{X}^{2}$ /df, AGFI, GFI, RMSEA, RMR, SRMR, IFI, NFI ölçütleri sayılabilir. $\mathrm{X}^{2} /$ serbestlik derecesi, örneklemden sağlanan veri ile kurulan modelin uyumunu sınamaktadır. İyi bir uyum için bu değerin, 3'ün altında olması beklenir. RMSEA(Tahmini Ortalama Karekök Hatası) değeri, örneklemden elde edilen kovaryasyon 
matrisinin model ile uyumunu sınamaktadır. $\mathrm{Bu}$ değerinde 0.08 'den küçük olması beklenmektedir. SRMR(Standartlaştırılmış Ortalama Hataların Karekökü), evren ve örneklemin kovaryasyon matrislerini kıyaslamaktadır. Aynı şekilde bu değerin de 0.08'den küçük olması gerekmektedir. GFI(Uyum İyiliği İndeksi) ve AGFI (Düzeltilmiş Uyum İyiliği İndeksi) modelin genel uyumunu sinamaktadır. Bu değerlerin 0.80 'den yüksek olması beklenmektedir. CFI (Karşılaştırmalı Uyum İndeksi), örneklem büyüklüğü ve serbestlik derecesini göz önünde bulundurarak, modelin temel model ile kıyaslamasını yapmaktadır. IFI (Artırmalı Uyum İndeksi), örneklem büyüklüğü ve karmaşıklık derecesine göre model uyumunu sınamaktadır. Bu değerlerin 0.90'dan büyük olması iyi uyumu göstermektedir. NFI(Normlaştırılmış Uyum İndeksi) değeri, örneklem hacminden etkilenen ve tüm değişkenlerin bağımsız olduğu sıfır modelin, $\mathrm{X}^{2}$ değeri ile, kurulmuş olan modelin $\mathrm{X}^{2}$ değerini karşılaştırarak değerlendirme yapan bir ölçüttür. Kabul değeri 0.90 ve üzeridir (Harrington, 2008, s. 51-53; Gürbüz ve Şahin, 2017, s. 332-333; Erkorkmaz vd., 2013, s. 213-215). Modelden elde edilen uyum indeks değerleri Tablo 1'deki gibidir.

Tablo 1. Uyum İndeks Değerleri

\begin{tabular}{lcccccccc}
\hline Ölçüt & $\begin{array}{c}\mathrm{X}^{2} / \text { Serbestlik } \\
\text { Derecesi }\end{array}$ & GFI & AGFI & CFI & NFI & IFI & RMSE & SRM \\
& & & & & & A & R \\
\hline $\begin{array}{l}\text { Kabul } \\
\text { edilebilir }\end{array}$ & $<$ & $>0.85$ & $>0.80$ & $>0.90$ & $>0.90$ & $>0.90$ & $<0.08$ & $<0.08$ \\
değer & & & & & & & & \\
\hline Model değeri & 1.266 & 0.95 & 0.88 & 1.00 & 0.98 & 1.00 & 0.066 & 0.021 \\
\hline
\end{tabular}

Modelin tüm uyum değerlerinin, kabul edilebilir değerlerin üzerinde olduğu tespit edilmiştir. İndeksler, elde edilen örneklem sayısının ve örneklemden elde edilen verilerin uygun ve tutarlı olduğunu; kurulan model ile verinin uyum gösterdiğini (fit) ortaya koymaktadır.

\section{İç Tutarlılık ve Zamana Göre Geçerlik Analizi}

Yapı geçerliliğin test edilmesi sonrasında, ölçeğin güvenirliği sınanmıştır. İç tutarlığın test edilmesinde, Cronbach Alpha değeri kullanılmıştır. Cronbach Alpha değeri, ölçme aracında yer alan önermelerin, kendi aralarındaki tutarlılığını sınamaktadır. Bir ölçüm aracıyla tek seferde yapılmış olan bir ölçümün, kavramsal olarak tutarlılı̆̆ını göstermektedir (Gürbüz ve Şahin, 2017, s. 315-316). Cronbach Alpha değerinin, en az 0.40 olması beklenmektedir. Ancak bu güvenirliğin düşük olduğunu göstermektedir. 0.80 ve üzeri değerler, bir ölçeğin iç tutarlılığın yüksek derecede güvenilir olduğunu ifade etmektedir (Lorcu, 2015). Bu çalışmada, Cronbach Alpha değeri, yüksek derecede güvenilir kategorisine giren, 0,941 olarak hesaplanmıştır (Tablo 2). 


\section{Cronbach Alpha}

Dile Getirme Davranışı Ölçeği

0,941

Ölçeğin zamana göre tutarlığını test etmek için ise, test-tekrar test uygulamasından faydalanılmıştır. 10 katılımcı ile 2 hafta arayla gerçekleştirilen anket uygulamasının, sonuçları arasındaki korelasyon değerlendirilmiştir. Böylece, ölçeğin zamana göre geçerlilik gösterip göstermediği sınanmıştır. Analiz sonucunda iki uygulama arasındaki korelasyon değeri 0,784 ve anlamlı bulunmuştur $(\mathrm{p}<0.05)($ Tablo 3$)$.

Tablo 3. Ilk ve Son Test Korelasyon Değeri

\begin{tabular}{ccccc}
\hline Değişkenler & Ort. & S.S. & İlk test & Son test \\
\hline İlk test & 32,9 & 4,25 & - & $0,784 *$ \\
Son test & 31,1 & 5,27 & $0,784^{*}$ & - \\
\hline *Spearman Korelasyon Katsayııı & & & &
\end{tabular}

\section{Tartışma ve Sonuç}

Peter Drucker tarafından ifade edilmiş olan “ölçemediğin şeyi yönetemezsin” anlayışı, yönetim bilimlerinde en önemli ilkelerden biridir. İnsan kaynakları yönetimi ve örgütsel davranış konularında da, iyileştirmeler yapılabilmesi ve yaklaşım tarzlarının belirlenebilmesi için, insan kaynağına yönelik yapıcı ölçümler oldukça kıymetlidir. Sosyal birer varlık olan insanların davranışları üzerine yapılan ölçümler, genellikle algı ve tutumların tespitine yöneliktir. Bu alanlarda, sosyal bilimlerin doğası gereği, kesin ve net bilgilere ulaşıldığını düşünmek yanıltıcı olmaktadır (Wallerstein, 2013). Ancak, algı ve tutumlara yönelik temel noktaların elde edilmesi, yönetim bilimlerinde, örgüt kültürünü yapıcı bir hale getirmek, insan kaynağının motivasyonunu arttırmak ve iyileştirmeler yapabilmek için kıymetli verilerdir. Ölçek geliştirme ve uyarlama çalışmaları, bu amaca hizmet eden, kapsamlı ve literatür için önem arz eden çalışmalardır.

$\mathrm{Bu}$ çalışmada, yöneticiler için motivasyonu arttırmak ve örgütsel gelişimi sağlamak için önemli araçlardan biri olan, dile getirme davranışının, değerlendirilebilmesi için uygun bir ölçüm aracı elde etmek amaçlanmıştır. Uyarlama aşamasında, dile getirme davranışının oldukça kıymetli olduğu, sağlık sektörü hedef olarak belirlenmiş ve idari birimlerden tıbbi birimlere kadar, farklı departman ve görevde yönetici, sorumlu ve ekip liderleri ile, Türkçe'ye çevrilen dile getirme davranışı ölçeği uygulaması gerçekleştirilmiştir. Sağlık sektörü; çalışanlar arası karşılıklı bağımlılı̆̆ın yüksek, matriks yapıda, ekip çalışmasına dayalı ve sürekli gelişmeyi gerektiren bir hizmet üretim alanı olması sebebi ile uygulama alanı olarak seçilmiştir.

Uygulama sonrası yapılan analizlerde, ölçeğin yapı geçerliliği şartlarını taşıdığı görülmüştür. Yüksek faktör yükleri ve açıklanan varyans oranları, dile getirme davranışı ölçeğinin, sağlık 
sektöründe önemli bir karşılığının olduğunu göstermektedir. Yöneticiler tarafından, çalışanların dile getirme davranışı sergileme beklentilerinin olduğu ve bu alana önem verdikleri görülebilmektedir. Doğrulayıcı faktör analizinin uyum indeksleri, kabul edilebilir değer aralıklarının üzerinde yer almıştır. Göstergelerden elde edilen değerlerin uygun olması, modelin, örneklem ile uyumlu olduğunu göstermektedir. Bu göstergeler de, ölçeğin sağlık sektörünü için uygulanabilir olduğunu göstermektedir. Son olarak, veri setine uygulanan iç tutarlılık ve test-tekrar test analizleri, ölçeğin güvenilir ve zamana göre geçerli olduğunu göstermiştir.

Tasarlanan ölçek, yöneticilerin kendilerine bağlı olan çalışanların, dile getirme davranışı düzeylerini değerlendirmelerini mümkün kılmaktadır. Böyle bir değerlendirme aracı, sektörel uygulamalarda, çalışanlara yönelik olarak tasarlanması düşünülen yeni yaklaşımlar için veri sağlayabilecektir. Yabancı literatürde dile getirme davranışının, liderlik (Duan vd., 2017), işe adanmışlik (work engagement) (Cheng vd., 2013), değişim ve inovasyon yönetimi (Guzman ve Espejo, 2018) gibi birçok farklı konuyla ilişkinin araştırıldığı görülmektedir. Ayrıca, sağlık sektöründe de (Morrow vd., 2016; Ünver, 2016) bu alanda araştırmaların yapıldı̆̆ görülmektedir.

$\mathrm{Bu}$ çalışmada geliştirilen ölçüm aracının, Türk yazınında dile getirme davranışının farklı değişkenler ile incelenmesi için çalışmalar yapılabilmesine katkı sunacağı düşünülmektedir. Ölçeğin farklı sektörler için de adapte edilebileceği düşünülmekte ve bu alanda çalışmalar yapılması önerilmektedir.

\section{Kaynakça}

Brown, P., \& Levinson, S.C. (1987). Politeness: Some universals in language usage. USA: Cambridge University.

Chamber, N. (2011). Leadership and governance. İçinde K. Walshe, \& J. Smith (Eds.), Healthcare management (pp. 377-400). McGraw Hill.

Cheng, J.W., Lu, K.M., Chang, Y.Y. \& Johnstone, S. (2013). Voice behavior and work engagement: The moderating role of supervisor-attributed motives. Asia Pacific Journal of Human Resources, 51(1), 81-102.

Comrey, A. L., \& Lee, H.B. (1992). A first course in factor analysis (2nd ed.). Psychology Press.

Detert, J.R., \& Burris, E.R. (2007). Leadership behavior and employee voice: Is the door really open. Academy of Management Journal, 50(4), 869-884.

Detert, J.R., \& Edmondson, A. C. 2011. Implicit voice theories: Taken-for-granted rules of selfcensorship at work. Academy of Management Journal, 54(3), 461-488.

Duan, J., Li, C., Xu, Y., \& Wu, C.H. (2017). Transformational leadership and employee voice behavior: A pygmalion mechanism. Journal of Organizational Behavior, 38(5), 650-670.

Erkorkmaz, Ü., Etikan, İ., Demir, O., Özdamar, K., \& Sanisoğlu, S.Y. (2013). Doğrulayıcı faktör analizi ve uyum indeksleri. Türkiye Klinikleri Dergisi, 33(1), 210-223. 
Guzman, F.A., \& Espejo, A. (2019). Introducing changes at work: How voice behavior relates to management innovation. Journal of Organizational Behavior, 40(1), 73-90.

Gürbüz, S., \& Şahin, F. (2017). Sosyal bilimlerde araştırma yöntemleri felsefe-yönetim-analiz. Ankara: Seçkin.

Harrington, D. (2008). Confirmator factor analysis. London: Oxford University.

Howard, T., Jacobson, K.L., \& Kripalani, S. (2013). Doctor talk: Physicians' use of clear verbal communication. Journal of Health Communication, 18, 991-1001.

Kim, J., MacDuffie, J.P., \& Pil, F.K. (2010). Employee voice and organizational performance: Team versus representative influence. Human Relations, 63(3), 371-394.

LePine, J.A., \& Van Dyne, L. (1998). Predicting voice behavior in work groups. Journal of Applied Psychology, 83, 853-868.

Liang, J., Farh, C. I., \& Farh, J.L. (2012). Psychological Antecedents of Promotiveand Prohibitive Voice: A Two-Wave Examination. Academy of Management Journal, 55, 7192.

Long, H. (2014). More than appropriateness and novelty: Judges' criteria of assessing creative products in science tasks. Thinking Skills and Creativity, 13, 183-194.

Lorcu, F. (2015). Örneklerle veri analizi: SPSS uygulamalı. Ankara: Detay.

Matthews, R.J. (2007). The measure of mind: Propositional attitudes and their attribution. London: Oxford University.

Maynes, T.D., \& Podsakoff, P.M. (2014). Speaking more broadly: An examination of the nature, antecedents, and consequences of an expanded set of employee voice behaviors. Journal of Applied Psychology, 99, 87-119.

McClean, E.J., Martin, S.R., Emich, K.J., \& Woodruff, C.T. (2018). The social consequences of voice: An examination of voice type and gender on status and subsequent leader emergence. Academy of Management Journal, 61, 1869-1891.

Milliken, F.J., Morrison, E. W., \& Hewlin, P. (2003). An exploratory study of employee silence: Issues that employees don't communicate upward and why. Journal of Management Studies, 40, 1453-1476

Morrison, E.W. (2014). Employee voice and silence. Annual Review of Organizational Psychology and Organizational Behavior, 1(1), 173-197.

Morrison, E.W. (2011). Employee voice behavior: Integration and directions for future research. The Academy of Management Annals, 5(1), 373-412.

Morrison, E.W.,Wheeler-Smith, S.L., \& Kamdar, D. (2011). Speaking up in groups: A crosslevel study of group voice climateand voice. Journal of Applied Psychology, 96, 183-191.

Morrow, K.J., Gustavson, A.M., \& Jones, J. (2016). Speaking up behaviours (safety voices) of healthcare workers: A meta synthesis of qualitative research studies. International Journal of Nursing Studies, 64, 42-51. 
Nunnally, J.C. (1978). Psychometric theory. McGraw-Hill.

Nunnualy, J.C., \& Bernstein, I. (1994). Psychometric Theory. McGraw-Hill.

Pett, M.A., Lackey, N.R., \& Sullivan, J. (2003). Making sense of factor analysis: The use of factor analysis for instrument development in healthcare research. SAGE.

Pinder, C.C., \& Harlos, K.P. (2001). Employee silence: Quiescence and acquiescence as responses to perceived injustice. Research in Personnel and Human Resources Management, 20, 331-369.

Schwappach, D., \& Richard, A. (2018). Speak-up related climate and its association with healthcare workers' speaking up and witholding voice behaviours: A cross-sectional survey in switzerland. BMJ Quality and Safety, 27(10), 827-835.

Ünver, S. (2016). Explaining service employees' voice behavior: A multilevel systems theory approach (Tez Numarası. 431519). [Doktora Tezi. Istanbul Bilgi Universitesi ].YÖK Tez Merkezi.

Wallerstein, I. (2013). Bilginin belirsizlikleri. Sümer.

Wu, J.B., Tsui A.S., \& Kinicki, A.J. (2010).Consequences of differentiated leadership in groups. Academy of Management, 53, 90-106.

\section{Ek: ÖIçek İfadeleri}

"Her bir ifade, ilgili ast veya çalı̧̧anı değerlendirmek üzere, yönetici/liderler tarafından 7'li Likert tipi ölçekte (1: kesinlikle katılmıyorum, 7: kesinlikle katılıyorum) puanlanır."

\section{Bu çalışan/meslektaş;}

(1) Çalışma ekibini etkileyen konular hakkında öneriler geliştirir ve bu önerileri dile getirir.

(2) Ekibi etkileyen sorunlarla ilgilenmeleri için ekip içerisindeki diğer kişilerle, konuşur ve onları cesaretlendirir.

(3) Ekip içerisindeki diğer bireylerle aynı fikirde olmasa veya diğer ekip üyeleri kendisinin fikirlerine katılmasalar dahi, çalışma konuları hakkındaki fikirlerini dile getirir.

(4) Çalı̧̧ma ekibinin faydasına olacak konularda bilgi düzeyini sürekli yüksek tutar.

(5) Çalı̧̧a hayatının kalitesini etkileyen konularla ilgilenir.

(6) Çalışma ekibi içerisinde yeni projeler geliştirilmesi veya iş yapma usullerinde değişiklik yapılması için,fikirlerini açıkça dile getirir. 